\title{
Demographic pattern of economic elder abuse Among Retired Army officers and men in Bauchi South Senatorial District, Bauchi State - Nigeria
}

\author{
Joseph Philip Dangbin, James Kyamru \\ Department of Physical Education, University of Nigeria, Nsukka, Enugu State, Nigeria
}

\begin{abstract}
The study investigated the demographic pattern of economic elder abuse - DPEEA among retired army officers and men (RAOM) in Bauchi South Senatorial District-BSSD, Bauchi State-Nigeria. One research question and a corresponding null hypothesis guided the study. The cross-sectional research design was used for the study. The population for the study was 2024 RAOM, while the sample for the study consisted of 204 RAOM. Researchers designed questionnaire validated by five experts was used for data collection. a reliability index of .85 was obtained through the outcome of pilot testing using split half method. Percentages was used to answer research question while chi-square statistic was used in testing hypothesis at .05 level of significance $(p$-value $=.05)$. The results of the study showed that DPEEA of RAOM of Christianity was more with cluster mean of $91.9 \%$ as against their Islamic counterpart of $89.9 \%$. Furthermore, that of the two religions of the RAOM, the RAOM of Christian fate were subjected to economic elder abuse - EEA more than their Muslims counterpart in delayed pension or periodic financial assistance (Christians' RAOM $=97.7 \%>$ Muslim RAOM $=91.2 \%$ ). The study further showed that a significant difference was found in the DPEEA of RAOM according to religion (Cal $\chi^{2}=68.91>\chi^{2}$ tab $=3.84$, df $=1, p<.05$ ). In line with the findings of the study, recommendations were proffered among which was that the Clergies and relevant agencies should endeavour to ensure that their congregations and people are encouraged to treat the elderly appropriately especially in the restoration of their dignity by appropriate treatment. This can be done when the elderly are taken care of by their people as they cater for their most fragile needs and demands; such as the need to be provided appropriate adequate meals, paying the elderly their entitlement of pension promptly, not compelling them to do poorly remunerated jobs among many others.
\end{abstract}

Keywords: Demographic pattern; Economic elder abuse; Retired army officers and men

\section{INTRODUCTION}

Population ageing in developed countries evolved gradually as a result of an earlier decline in fertility and improved living standards for majority of the population over a relatively long period of time after the industrial revolution. In developing nations, population ageing is occurring more rapidly because of rapid fertility decline and an increasing life expectancy (United Nations, 2007).

Studies by Holmstrom (1994) and Ageing and Development (2000) have shown that such elderly persons are subjected to abuse. The abuse of older people by family members dates back to ancient times. Initially, it was seen as a social welfare issue and subsequently a problem 
of elderly (ageing), abuse of the elderly, like other forms of family violence, has developed into a public health and criminal justice concern. These two fields - public health and criminal justice - have therefore dictated to a large extent how abuse of the elderly is viewed, how it is analyzed, and how it is dealt with (Keikelame \& Ferreira, 2000). United Nations Population Division, UNPD, (2002) noted that abuse of older people is referred to as elder abuse. It was first described in British scientific journals in 1975 under the term granny battering (mistreatment of the older people). Elder abuse is not restricted to developed nations of the world but also prevalent in developing nations of Asia, Latin America and Africa (UNDP, 2002). Following from the antecedents above, it implies that vulnerable persons because of their frail nature can be abused.

Abuse is a multi-dimensional phenomenon that encompasses a broad range of behaviour, events, and circumstance unlike random acts of violence or exploitation (National Academies of Sciences, NAS, (2009). Elder abuse as perceived by NAS is intentional actions that cause harm or create a serious risk or harm (whether or not harm is intended) to a vulnerable elderly by a caregiver or other person who stands in a trusted relationship to the elder. Elder abuse is the use of something in a way that is wrong or harmful to the elderly (Ageing and Development, 2000). In addition, it encompasses any act of commission or omission that results in harm or threatened harm to the health and welfare of an older adult. In the present study, NAS' (2009) definition of elder abuse shall be adopted as the operational definition. They perceived elder abuse as all intentional actions that cause harm or create a serious risk or harm (whether or not harm is intended), to a vulnerable elderly by a caregiver or other person who stands in a trusted relationship to the elder.

Elder abuse often than not is undetected because victims are afraid to speak out. Many elderly people worry that if they report bad treatment; their abusers will become more violent or may try to have them institutionalized (Macionis, 2009). Some studies by Pillemer (1988); Talara (1993) and Perrin (1997) showed that only ten per cent of all actual abuse cases were reported. The existing statistics on elder abuse may not reveal vividly this unprecedented phenomenon. National Elder Abuse Incidence Study (NEAIS, 2009) reported that the incidence of elderly abuse have some types of abuse and neglect which is related to age, minority group, status, gender, and according to physical and mental frailty for incidents reported which could occur at homes or institutions (elderly home) at a given period in different forms.

Elder abuse being a public health problem as revealed by (Gilliland, Picado, 2000; NPC, 2006) is perpetrated in diverse forms. NPC further indicated that elder abuse is of different forms, namely: physical, psychological (emotional and or verbal aggression), financial or economic abuse and neglect that results in unnecessary suffering, injury, pain, loss, and or violation of human rights and decreased quality of life. Whether the behaviour is labeled as abusive, neglectful, or exploitative may depend on the frequency of the mistreatment, duration, intensity, severity, consequences, and cultural context in which it exists. Elder abuse may have characteristics.

Forms of abuse are characterized by misuse of power and control by one person over another who are or have been in an intimate relationship. It can occur in mixed gender relationships and same gender relationships and has profound consequences for the lives of children; individuals and families including communities in Bauchi State, Nigeria. It may, as earlier indicated be physical, sexual, economic or material, personal and self and psychological forms. In the context of this study, economic abuse will be discussed.

Economically, elder(s) can be victims of abuse. Tjadan and Theonnes (2000) viewed economic or material abuse of the elderly as when the abuser has unauthorized control over the 
victim's money and other economic resources. In its extreme form, this involves putting the victim on a strict "allowance", withholding money at will and forcing the victim to beg for money until the abuser gives them some money (Economic Abuse, 2009).

Among victims who are still living with their perpetrators of economic elder abuse, high amounts of stress; fear and anxiety may be a common experience. Depression may also be common, as victims are made to feel guilty for provoking the abuse and are constantly subjected to intense criticism. It is reported that sixty per cent of economic elder abuse victims meet the diagnostic criteria for depression, either during or after termination of experience, and have greatly increased the risk of suicide (Barnnet, 2001). In addition to depression, victims of economic elder abuse also may commonly experience long-term anxiety and panic, and may likely meet the diagnostic criteria for generalized anxiety disorder and panic disorder. Vitanza (1995) submitted that symptoms of abuse are generally experienced for a long span of time after the victim has left this dangerous situation, which can be manifested in different pattern.

Pattern according to Cowie (1990) refers to pattern as the various forms that something may take. Henslin (2008) defined pattern as recurring characteristics or events. Farlex (2008) indicated that pattern has to do with any set of conventional principles and expectations that are binding on any person who is a member of a particular group. Demographic pattern according to Ajomale (2007) occur as age, gender, and marital status, level of education, religion, occupation, socio-economic and health status as well as race and so on. Economic elder abuse can also assume different pattern (Wahl \& Purdy, 2008), such as spatial; temporal and demographic. Demographic pattern in this study is the regular form of religion though which economic elder abuse may be perpetrated by adherents of religious affiliation.

Incidentally, investigating the influence of religion on economic elder abuse perpetration among RAOM may provide a viable platform for proffering suitable solution, if found to be true that will aimed at combating this bizarre phenomenon among RAOM in BSSD and Nigerian army in general. Army is the branch of a country's armed forces, trained to fight on land (Encarta Dictionary, 2009). Hornby (2005) indicated that army is a large organized group of officers and men who are trained to fight on land, that is, people who have the obligation to defend their nation and needed to be honoured as at when due. Army is of different category or cadre (officers and men). To be an 'officer', one has to be specially commissioned by the king or sovereign, while men are non-commissioned army (Omoigui, 2007). Army officers and men in this study are those officers and men who offered their services to their nation and are of different ranks that are no longer in the services of the army who are therefore retired.

Retirement is defined as the act of stopping work for the fact that an individual has reached a particular age (Hornby, 2005). As viewed by Henslin (2008), retirement is a mutually beneficial arrangement between two parts of society. He further submitted that retired army officers and men are those who have offered their lives in serving their nation, and are no more in active service.

In the light of the preceding submissions above, Maduewesi (1988) suggested measures to be taken in order to remedy elder abuse among which is to conduct researches which are aimed at investigating impacts of abuse on the elderly. One of the primary purposes of such researches, he suggested, would be to inform the entire populace on the consequences of elder abuse. This informs the investigator's decision to embark on this study among retired army officers and men in Bauchi South Senatorial District of Bauchi State-Nigeria. 


\section{STATEMENT OF THE PROBLEM}

The elderly are the progenitors of human species upon which the succeeding generations depend for survival, transmission of societal values and pattern maintenance (Brubakar, 2006). Due to their fragile health status and the indispensable roles the elderly performs in the transmission of societal values and pattern maintenance, the elderly ought to be cared for and not abused. The above assertion is in consonance with part of United Nations (2007) convention on the right of the elderly that makes provision for protection of elderly persons from all forms of mistreatment or inhuman treatment.

Studies by NPC (2006); Ajomale (2007) and NEAIS (2009) have revealed and established cases of elderly abuse among elderly peoples' populations in Nigerian societies but there exists dearth of documented information on pattern of elder abuse among this vital stratum of the Nigerian citizenry including RAOM in BSSD of Bauchi State. This situation poses the question what pattern of abuse exists among RAOM in BSSD of Bauchi State?

Following from the above, one may ask as follows: what is the DPEEA of RAOM in BSSD? This is the main, problem of the study. To further guide the study, a null hypothesis of no significant difference in the DPEEA of RAOM according to religion was posed and tested at .05 level of significance.

\section{SIGNIFICANCE OF THE STUDY}

The present study was designed to determine the DPEEA of RAOM in BSSD, Bauchi state-Nigeria. Data generated would be useful to religious bodies, army officers and men as well as researchers.

Religious bodies would use the findings of the study to serve as a means of reminder to them on issues concerning the ways their followers' treat RAOM and other elderly ones in their area. In addition, the RAOM and their authorities as well as community leaders would use the information if properly implemented by the aforementioned authorities will perpetuate peaceful co-existence, tolerance and forestall abuse among retirees located across the District. Moreover, the findings would serve as a baseline data that would help as a resource for reference. In addition, the gap created by this study would be filled by other researchers' future studies.

\section{METHODS}

To achieve the purpose of this study, the cross-sectional survey research design was employed. The population for this study consisted of all the RAOM in BSSD Bauchi State. The total population of RAOM, in BSSD was two thousand and twenty four (2024) (Federal Pay Office, Bauchi, 2010). The sample for the study consisted of 204 subjects representing 10 per cent of the RAOM in BSSD, Bauchi State. This was in line with Nwana's (1990) rule of thumb which stated that when the population is a few hundreds, the sample size should be 4050 per cent. If they are many hundred, 20 per cent of the population should be the sample size; when a few thousands, 10 per cent of them will do; and if several thousands, 2-5 per cent of the population will be considered representative. 
The Bauchi South Senatorial District was stratified into Christian and Moslem dominated LGAs. The use of proportionate sampling technique to select 50 per cent of LGAs from 15 LGAs and purposive sampling were used to arrive at a sample of 204 RAOM.

The instrument for data collection was the researcher-designed questionnaire which was called pattern of economic elder abuse questionnaire (PEEAQ). The reliability of the instrument was determined through the outcome of pilot testing using split half method, and reliability index of .84 was obtained. Two hundred and two questionnaires were correctly filled and were used for the study.

The information from the questionnaire was coded using the Statistical Package for Social Sciences (SPSS) batch system for analyzing data. Cluster means and proportions or percentages were used for providing answers to research question posed on DPEEA. Chisquare statistic was used to test the hypothesis of no significant difference and verified at.05 level of significance $(\mathrm{p}<.05)$.

\section{1. Research Question 1}

What is the DPEEA of RAOM by religion? Data answering this question are contained in Table 1.

Table 1. DPEEA of RAOM according to Religion $(n=202)$.

\begin{tabular}{|c|c|c|c|c|}
\hline \multirow{3}{*}{ Items of EEA } & \multicolumn{4}{|c|}{ Religion } \\
\hline & \multicolumn{2}{|c|}{$\begin{array}{c}\text { Christianity (Christians) } \\
\qquad(\mathrm{n}=88) \\
\text { Yes }\end{array}$} & \multicolumn{2}{|c|}{$\begin{array}{c}\text { Islam (Muslims) } \\
(\mathrm{n}=114) \\
\text { Yes }\end{array}$} \\
\hline & $\mathrm{f}$ & $\%$ & $\mathrm{f}$ & $\%$ \\
\hline Compelled you to perform poorly remunerated jobs & 82 & 93.2 & 100 & 87.7 \\
\hline Rejection from financially gainful employment & 84 & 95.5 & 104 & 91.2 \\
\hline Delayed pension/periodic financial assistance & 86 & 97.7 & 104 & 91.2 \\
\hline Extortion of money/valuables by relations & 82 & 93.2 & 102 & 89.5 \\
\hline Cluster mean & & 91.9 & & 89.9 \\
\hline
\end{tabular}

Table 1 show that the cluster means of DPEEA of the RAOM by religion of Christianity was more with cluster means of $91.9 \%$ as against their Muslims counterparts of $89.9 \%$. Furthermore, the results in Table 1 further show that of the two religious affiliations of the RAOM, the RAOM of Christian fate were subjected to economic elder abuse more than their Muslims counterparts as follows: "delayed pension or periodic financial assistance" (Christians' RAOM $=97.7 \%>$ Muslim RAOM $=91.2 \%$ ); "rejection from financial assistance" (Christian RAOM $=95.5 \%>$ Muslims RAOM =91.2 \%); "extortion of money or valuables by relations" (Christian RAOM $=93.2 \%>$ Muslims RAOM $=89.5 \%$ ), and 
"compelling elders to perform poorly remunerated jobs" (Christian RAOM $=93.2 \%>$ Muslims RAOM = 87.7\%).

\section{Hypothesis 1}

There is no significant difference $(\mathrm{p}<.05)$ in the pattern of EEA according to religion. Data verifying this hypothesis are contained in Table 2.

Table 2. Summary of Chi-square $\left(\chi^{2}\right)$ Analysis of no Significant Difference in the DPEEA according to Religion $(\mathrm{n}=202)$.

\begin{tabular}{|c|c|c|c|c|c|c|}
\hline Religion & $\mathrm{n}$ & Cal $\chi^{2}$ value & df & $\chi^{2}$ & Tab value & Decision \\
\hline \multirow[t]{2}{*}{ Christianity } & 88 & & & & & \\
\hline & & 68.91 & 1 & & 3. 84 & Rejected \\
\hline Islam & 114 & & & & & \\
\hline
\end{tabular}

Table 2 indicates that $\chi^{2}$ cal value of test of hypothesis of there is no significant difference in the pattern of elder abuse according to religion ( $\mathrm{Cal} \chi^{2}=68.91>\chi^{2}$ tab $=3.84$, $\mathrm{df}=1, \mathrm{p}<.05$ ) was greater than the observed $\chi^{2}$ table value. The hypothesis of no significant difference in the DPEEA according to religion was, therefore, rejected. This implies that there was a significant difference in the pattern of EEA of RAOM based on religion.

\section{DISCUSSION OF FINDINGS}

The results in Table 1 show that the DPEEA of the RAOM of the Christians religion was more with the cluster means of $91.9 \%$ as against their Muslims counterparts of $89.9 \%$ was not surprising because elder abuse has no social boundaries (Thomas, 2014). In addition, the finding was not expected because cultural and religious values and traditions of people ought to mitigate abuse and neglect of elders (Nerenberg, 2008). Submitting on the issue on EEA, Oyedokun and Awolowo (2007) posited that religious affiliation was a significant predictor of holding on to mixed views that Nigerian men hold on to traditional ideas. However, religion supposes to play a sacred role in shaping individuals but in this case; it may have been considered a mere culture. The respondents' position on EEA may have been so due to personal attributes of affiliations, level of education, place of residence and wealth index or other parameters. The implication of this finding is that religiosity may not have promoted the practice of moral values in stopping EEA even in the area of study. This implies that government relevant agencies as well as religious organizations should ensure that the 
promotion of moral values through sensitization of their members as a matter of urgency should be undertaken, as this would be needed to forestall and redress this anomaly.

Table 2 results indicate that a significant difference was found in the DPEEA of RAOM according to religion ( $\mathrm{Cal} \chi^{2}=68.91>\chi^{2} \mathrm{tab}=3.84, \mathrm{df}=1, \mathrm{p}<.05$ ). This finding was not surprising because Oyedokun (2003) submitted that religious affiliation was significant predictor of holding on to EEA. This finding was expected because it conforms to the position of About Domestic Violence (2007) that EEA can happen regardless of race, age (elderly inclusive), sexual orientation, and religion.

\section{CONCLUSIONS}

Based on the findings of the study, the followings conclusions were made:

1. The DPEEA of the RAOM of the Christian religion was more with the cluster means of $91.9 \%$ as against their Muslims counterpart of $89.9 \%$.

2. There was a significant difference in the DPEEA of RAOM according to religion (Cal $\left.\chi^{2}=68.91>\chi^{2} \mathrm{tab}=3.84, \mathrm{df}=1, \mathrm{p}<.05\right)$.

\section{Recommendations}

In view of the findings of this study, the following recommendations were proffered:

1. The Clergies and relevant agencies should endeavour to ensure that their congregations and people are encouraged to treat the elderly appropriately especially in the restoration of their dignity by appropriate treatment. This can be done when the elderly are taken care of by their people as they cater for their most fragile needs and demands; such as the need to be provided appropriate adequate meals, paying the elderly their entitlement of pension promptly, not compelling them to do poorly remunerated jobs among many others.

2. Government relevant agencies as well as religious organizations should ensure that the promotion of appropriate moral values should be preached and exercised. This can be realized through sensitization of their subjects to ensure that they clean the elderly urinals, convenience, clothes and living place among many others. Relations of the elderly should as a matter of urgency avoid the extortion of monies or valuables of the elderly as this can make them have some negative feelings to living.

\section{References}

[1] About Domestic Violence (2007). U.S Department of Justice. Retrieved April 24, 2010 from http://www. usdoj.gov/ ovw/ domviolence.htm.

[2] Ageing and Development (2012). Witchcraft: A violent threat 6:9. USA: Ageing 20(1), 41-47.

[3] Ajomale O., Sociology of Ageing 6(2) (2007) 12 -17.

[4] Brubakar J. (2006). Family relationships in later life. California: Wadsworth press. 
[5] Cowie A. P. (ed.) (1990). Oxford Advanced Learner's Dictionary of Current English. Oxford: Oxford University Press.

[6] Farlex T. (2008). The American heritage Dictionary. Published by Houghton Miffin Company. Accessed on April 10, 2011, from, http://medicaldictionary. The free Dictionary. Com/ adolescent $>$ adolescent $</ \mathrm{a}>$,

[7] Henslin J. M. (2008). Sociology a down - to - earth approach. ( $9^{\text {th }}$ Ed.). U.S.A: library of congress.

[8] Hornby A. S. (2008). Oxford Advanced Learner's Dictionary. (9 $9^{\text {th }}$ ed.). New York U.S.A: Oxford University Press.

[9] Keikelame J., Ferreira M. (2000.). Mpathekombi, ya bantuabadala: elder abuse in black townships. Human Sciences Research Council and University of Cape Town Centre for Gerontology. Cape Town: on the Cape Flats. 30.

[10] Macionis J. J. (2009). Social Problems. (3 $3^{\text {rd }}$ ed). New Jersey: Pearson Education. Inc.

[11] Microsoft Encarta (2009). Concept of Army officers. 1993-2008 Microsoft Corporation.

[12] National Academy of Sciences-NAS (2012). Science, evolution, and creationism: A brochure on the book of the same title. NAS, USA.

[13] National Elder Abuse Incidence Study -NEAIS Final Report (2009). Prepared for the administration for children and families and the administration on aging in the U.S. department of health and human services by the National Center on Elder Abuse at the American Public Human Services Association in Collaboration with Westar, Inc. (Formerly the American Public).

[14] National Elder Abuse Incidence Study -NEAIS Final Report (2012). Prepared for the administration for children and families and the administration on aging in the U.S. department of health and human services by the National Center on Elder Abuse at the American Public Human Services Association in Collaboration with Westar, Inc. (Formerly the American Public).

[15] National Population Commission-NPC- (2006). Population census of the federal republic of Nigeria: Preliminary Report United Nations Population Division (2005).

[16] Nerenberg L. (2008). Elder abuse prevention: Emerging trends and promising strategies. New York: Springer Publishing Company, LLC.

[17] Nwana O. C. (1990). Introduction to educational research. Ibadan: Thomas Nelson.

[18] Omoigui N. A. (2007). Military Ranks of the Nigerian Armed Forces. The History behind those names. Retreived.3/3/2011 from http://lcweb2.loc.gov/frd/cs/nigeria/ng05_02i.pdf

[19] Pillemer K., Finkelhor D., The Gerontologist 28(51) (1988) 57.

[20] Pridemore W. A., Andrew I., Spivak M. A. (2003). Patterns of Suicide mortality in Russia. 
[21] Tatara T., Broughton D. (1993). National Aging Resource Center on Elder Abuse (NARCEA).Institutional Elder Abuse: A Summary of Data Gathered From State Units on Aging, State APS Agencies and State LTC Ombudsman Programs National Aging Resource Center on Elder Abuse (NARCEA); Agency Report .Washington, D.C: 15 (P5769) 9.

[22] Thomas R. (2014). Elder Abuse in the United States. Accessed on 18/5/2014: http://rebthomas.hubpages.com/hub/Elder-Abuse-in-the-United-States

[23] Tjaden P., Thoennes N. (2000). Full report of the prevalence, incidence, and consequences of violence against women: Findings from the national violence against women survey. Washington, DC: U.S. Department of Justice, Office of Justice Programs. Publication No. NCJ183781.

[24] United Nations (2012). World Youth Report. Young People's Transition to adulthood: Progress and challenges. New York: United Nations.

[25] Wahl J., Purdy S. (2008). Advocacy Centre for the Elderly (ACE) and Community Legal Education Ontario (CLEO). London: 291 King Street, 4th Floor London ON N6B 1R8 Retieved:17/10/2010 from:

www.attorneygeneral.jus.gov.on.ca/english/family/pgt. 